\title{
Physiological stress responses in the warm-water fish matrinxã (Brycon amazonicus) subjected to a sudden cold shock
}

\author{
Luis Antonio Kioshi Aoki INOUE ${ }^{1}$, Gilberto MORAES², George K. IWAMA³ ${ }^{3}$ Luis Orlando Bertola AFONSO ${ }^{4}$
}

\begin{abstract}
The present work evaluated several aspects of the generalized stress response [endocrine (cortisol), metabolic (glucose), hematologic (hematocrit and hemoglobin) and cellular (HSP70)] in the Amazonian warm-water fish matrinxã (Brycon amazonicus) subjected to an acute cold shock. This species farming has been done in South America, and growth and feed conversion rates have been interesting. However, in subtropical areas of Brazil, where the water temperature can rapidly change, high rates of matrinxã mortality have been associated with abrupt decrease in the water temperature. Thus, we subjected matrinxã to a sudden cold shock by transferring the fish directly to tanks in which the water temperature was $10^{\circ} \mathrm{C}$ below the initial conditions (cold shock from $28^{\circ} \mathrm{C}$ to $18^{\circ} \mathrm{C}$ ). After $1 \mathrm{~h}$ the fish were returned to the original tanks $\left(28^{\circ} \mathrm{C}\right)$. The handling associated with tank transfer was also imposed on control groups (not exposed to cold shock). While exposure to cold shock did not alter the measured physiological conditions within $1 \mathrm{~h}$, fish returned to the ambient condition (water at $28^{\circ} \mathrm{C}$ ) significantly increased plasma cortisol and glucose levels. Exposure to cold shock and return to the warm water did not affect HSP70 levels. The increased plasma cortisol and glucose levels after returning the fish to warm water suggest that matrinxã requires cortisol and glucose for adaptation to increased temperature.
\end{abstract}

KEY WORDS: matrinxã, cold shock, stress, HSP70.

\section{Respostas fisiológicas ao estresse do peixe de águas tépidas matrinxã (Brycon amazonicus) submetido à queda brusca de temperatura}

\begin{abstract}
RESUMO
O presente trabalho avaliou as principais respostas fisiológicas e celulares [endócrino (cortisol), metabólico (glicose), hematológico (hematócrito and hemoglobina) e celular (HSP70)] ao estresse de um peixe de águas tépidas, o matrinxã (Brycon amazonicus), quando submetido a um choque térmico frio abrupto. Essa espécie vem sendo amplamente cultivada na América do Sul por apresentar excelentes índices zootécnicos de crescimento e conversão alimentar. Entretanto, os produtores rurais encontram limitaçôes no manejo do matrinxã, quando criado em regiōes mais frias que sua região de origem, a Bacia Amazônica. Assim, o matrinxã foi submetido a um choque frio através da transferência direta dos peixes para tanques com água fria a $18^{\circ} \mathrm{C}$. Após $1 \mathrm{~h}$, esses peixes retornaram a suas caixas de origem a $28^{\circ} \mathrm{C}$. O manuseio de peixes necessário para conduzir o choque térmico experimental foi também imposto aos grupos controle, sendo, entretanto, evitada a água fria. $\mathrm{O}$ matrinxã demonstrou claros sinais de estresse fisiológico durante os procedimentos experimentais. Porém, essas respostas não foram associadas ao choque frio, mas sim ao choque quente por ocasião da volta dos peixes para as caixas de origem. As respostas primárias e secundárias de estresse foram evidentes através das análises plasmáticas de cortisol e glicose. Já o hematócrito, a hemoglobina e as expressões da proteína de estresse, HSP70, não foram afetadas. Nossos resultados sustentam que o matrinxã falhou em responder ao choque térmico frio, mas não ao choque térmico quente, que é um estressor evidentemente associado à origem natural dessa espécie de águas de elevadas temperaturas.
\end{abstract}

PALAVRAS-CHAVE: matrinxã, choque térmico, estresse, HSP70.

\footnotetext{
${ }^{1}$ Empresa Brasileira de Pesquisa Agropecuária, Embrapa Amazônia Ocidental, CP 319, CEP 69010 970, Manaus, AM, Brasil.

${ }^{2}$ Departamento de Genética e Evolução (DGE), Universidade Federal de São Carlos (UFSCar), CP 676, CEP 13565-905, Sao Carlos, SP, Brasil.

${ }^{3}$ Department of Biology, Acadia University B3H 4P4. Wolfville, NS, Canada.

${ }^{4}$ Institute for Marine Biosciences, National Research Council of Canada (NRC/CNRC), 1411 Oxford St. B3H 3Z1. Halifax, NS, Canada.

* Corresponding author. Tel 55163351 8376, fax 5516351 8377. Email address: gil@power.ufscar.br
} 


\section{INTRODUCTION}

Among the natural stressors fish can experience throughout their life cycle are thermal changes. Fluctuations in water temperature can result from a transient (daily change) or a seasonal change. In either case, to deal with the environmental change, fish respond by altering physiological functions including those associated with the stress response (Barton \& Iwama, 1991). The physiological stress response in fish is mediated by the neuro-endocrine system and includes the release of hormones such as cortisol and adrenaline (Barton \& Iwama, 1991). In response to most stressors fish will exhibit an increase in plasma cortisol levels, which is generally followed by an elevation in plasma glucose levels. A physiological stress response also occurs at the cellular level, which is characterized by the induction of a conserved group of proteins named the heat shock proteins (HSP). The HSPs have been measured in almost all organisms including fish (Iwama et al., 2004). Most of the research is focused on the $70 \mathrm{kDA}$ family (HSP70), and several stressors have shown to alter the HSP70 response in fish (Basu et al., 2002; Iwama et al., 2004; Afonso et al., 2004).

A clear relationship between these two levels of responses (endocrine and cellular) has not yet been demonstrated in fish. Although most stressors can elicit an endocrine response, a corresponding cellular response does not always occur. For instance, handling can clearly affect the endocrine response (Vijayan et al., 1997) without eliciting an HSP response in fish (Vijayan et al., 1997; Washburn et al., 2002).

Matrinxã Brycon amazonicus (Günther, 1869) (Characidae) that lives in the warm waters of the Amazon basin has lately gained attention from the sport fishing industry in Brazil, mainly due to the aggressive behavior and fierce attack to fishing baits. This has led to a high demand for cultured matrinxã, which are sold live. In the southeast Brazil, where the climate is predominantelly sub-tropical, high rates of mortality have been associated with abrupt decreases in the water temperature.

Changes in the endocrine and cellular responses to acute heat shock have been studied in fish. Concomitant increase cortisol and HSP70 levels have been documented in rainbow trout (Oncorhynchus mykiss) exposed to heat shock (Basu et al., 2001). The same authors demonstrated that tilapia (Oreochromis mossambicus) subjected to heat shock only elicited the cortisol response. Atlantic salmon (Salmo salar) also increased HSP70 when exposed to heat shock (DuBeau et al., 1998). Palmisano et al. (2000) demonstrated that chinook salmon (Oncorhynchus tshawytscha) exposed to heat shock presented increased levels of HSP90 messenger RNA, but there was no concomitant increase in plasma cortisol levels.

Studies have also shown an endocrine stress response change in fish exposed to cold shock (Barton \& Peter, 1982; Tanck et al., 2000; Chen et al., 2002). In these three studies, increased plasma cortisol levels were observed in rainbow trout, common carp (Cyprinus carpio) and tilapia aurea (Oreochromis aureus), respectively, exposed to cold shock (in different experimental conditions). Yamashita et al. (1996) have shown increased mRNA coding for a $70 \mathrm{kDa}$ cold-induced protein that was homolog of the mammalian vasolin-containing protein and yeast CDC48p. However, zebrafish (Danio rerio) embryonic cell line (ZF4) subjected to cold shock did not elicit an HSP70 response (Airaksinen et al., 2003). Ju et al. (2002), using cDNA micro-arrays, reported a transient increase in HSP70 transcript in brain tissue of catfish exposed to cold acclimation. In most of these studies, however, the species investigated are adapted to live in cold water. Furthermore, none of the studies explored the relationship between the endocrine and cellular responses.

In this study we investigated the stress response in a tropical fish during and after exposure to an acute cold shock $\left(10^{\circ} \mathrm{C}\right.$ decrease in water temperature). We determined the levels of hematocrit, total hemoglobin, cortisol, glucose and gills HSP70 before a $1 \mathrm{~h}$ cold shock, just after the cold shock had finished, and at several times (1, 3, 6, 12, and 24h) during recovery.

\section{MATERIAL AND METHODS}

\section{FISH}

Juvenile matrinxã (mean weight $91.3 \pm 24.8 \mathrm{~g}$ and length of $18.8 \pm 1.7 \mathrm{~cm}$ ) were purchased from a commercial fish farm, and held in an indoor closed water system $\left(2-\mathrm{m}^{3}\right.$ tanks; 75 fish $/ \mathrm{m}^{3}$ ) for 6 months prior to the experiment.

\section{COLD SHOCK: TREATMENTS AND PROTOCOL}

Initially, 240 fish were equally distributed in six 2000-L tanks supplied with freshwater (in closed water system) and aeration. Fish were acclimated for 3 weeks, and we used 40 fish per tank and 3 replicates per treatment (cold shock and control) for the experiment. Water temperature $\left(28 \pm 2.4^{\circ} \mathrm{C}\right)$, dissolved oxygen $(5.66 \pm 0.09 \mathrm{mg} / \mathrm{L})$, conductivity $(74.3 \pm 4.8$ $\mu \mathrm{S} / \mathrm{cm}$ ) and $\mathrm{pH}(7.0)$ were constant throughout this period, and adequate for this species (Arana, 1997). During this period fish were fed daily a commercial diet (32\% crude protein) at $2-3 \%$ of body weight. Food was withheld $24 \mathrm{~h}$ before the onset of the cold shock. The cold shock treatment consisted of transferring directly the fish from each replicate group to 200-L tanks in which the water had been decreased in $10^{\circ} \mathrm{C}$. We decreased the water temperature by adding ice to the tanks. The ice was previously made using the same water supplied to the experimental tanks. An YSI model 55 probe was used during the $1 \mathrm{~h}$-cold shock to monitor water temperature and dissolved oxygen concentration. To account for handling procedures, fish from the control group were transferred to tanks with the same water temperature 
$\left(28^{\circ} \mathrm{C}\right)$. The treatment lasted $1 \mathrm{~h}$ and then fish were returned to the 2000-Ltanks.

\section{FISH SAMPLING}

Three fish from each replicate were sampled before (Bef), immediately after (Aft) the $1 \mathrm{~h}$ treatment, and at 1, 3, 6, 12, and $24 \mathrm{~h}$ during recovery $(\mathrm{N}=9$ at each sampling time). At each sampling time, fish were removed from the tanks and killed by a sharp blow to the head. Weight $(\mathrm{g})$ and length $(\mathrm{cm})$ were recorded from each fish. Blood was collected from the caudal vein using a $3 \mathrm{ml}$ heparinized syringe, and centrifuged at $12000 \mathrm{~g}$ for 3 min to collect plasma. Gills samples (approximately $100 \mathrm{mg}$ ) were removed quickly from each fish and immediately frozen in liquid nitrogen. Plasma and tissues were stored at $-80{ }^{\circ} \mathrm{C}$ until assays.

\section{MEASUREMENTS}

\section{HEMATOCRIT AND TOTAL HEMOGLOBIN LEVELS}

Microcapillary tubes were used for microhematocrit determinations on whole blood (Collier, 1944). Total hemoglobin content was measured according to Drabkin (1948).

\section{PLASMA CORTISOL AND GLUCOSE LEVELS}

Plasma cortisol levels $(\mathrm{ng} / \mathrm{ml})$ were measured in duplicate using an enzyme-linked immunosorbent assay kit from Neogen Corporation (Lansing, MI, USA) (Basu et al., 2001). The absorbance was read on a Molecular Devices SpectraMax 340PC microplate reader $(\lambda=450 \mathrm{~nm})$. Plasma glucose levels $(\mathrm{mg} / \mathrm{dl})$ were measured in triplicate using a modified Trinder (1969) enzymatic assay available in kit form (Sigma, Mississauga, ON, Canada). The absorbance was read on a microplate reader $(\lambda=505 \mathrm{~nm})$.

\section{HSP70 LEVELS - SDS-PAGE AND IMMUNOBLOTTING}

Gill samples were homogenized in ice-cold lysis buffer (containing 100mM Tris-HCl (pH 7.5), 0.1\% SDS, $1 \mathrm{mM}$ ethylenediaminetetraacetic acid (EDTA), $1 \mu \mathrm{M}$ pepstatin A, $1 \mathrm{mM}$ phenylmethylsulfonyl fluoride (PMSF), $1 \mu \mathrm{M}$ leupeptin, and $0.01 \mu \mathrm{M}$ aprotinin). The tissue lysates were cleared in a microcentrifuge at $16,500 \mathrm{~g}$ for $3 \mathrm{~min}$ at room temperature. Ten microlitres of supernatant was taken for protein determination with the bicinchoninic acid (BCA) assay using bovine serum albumin (BSA) as a reference. A 1:1 solution of supernatant and SDS-sample dilution buffer (Laemmli, 1970) was boiled for $3 \mathrm{~min}$ and then frozen at -70 ${ }^{\circ} \mathrm{C}$ until HSP70 quantification.

Levels of HSP70 protein were measured using the discontinuous SDS-polyacrylamide gel electrophoresis (SDS-PAGE) method of Laemmli (1970). Samples of equal total protein content $(20 \mu \mathrm{g})$ were resolved with a
$4 \%$ stacking and $12 \%$ separating gels on a Mini-Protean II electrophoresis cell (Bio-Rad Laboratories, Hercules, CA, USA). Prestained molecular weight markers (Invitrogen life technologies, Carlsbad, CA, USA) and a positive control (rainbow trout gonad (heat shocked) cell lysates - Stressgen Biotechnologies Corp., Victoria, BC, Canada) were loaded to every gel. Following electrophoretic separation, the proteins were transferred onto nitrocellulose membranes for immunoblotting (Basu et al. 2001). Membranes were then incubated for $35 \mathrm{~min}$ in the primary antibody monoclonal anti-heat shock protein 70 antibody (produced in mouse 1:10000 dilution (H5147 Sigma, Saint Louis, MI, USA)). This antibody recognizes both the constitutive and inducible forms of HSP70. Following, membranes were washed in tris buffer saline-tween 20 (TBS-T) and incubated with the secondary antibody (goat anti-mouse peroxidase conjugate 1:10000 dilution (A-9917 Sigma)) for 35min. Both antibodies were diluted with $2 \%$ skim milk powder in TBS. Membranebound antibody was detected using a chemiluminescence substrate (ECL - Wetern blotting detection reagents RPN 2108, Amersham Biosciences, England) and the bands were quantified by densitometry (Bio-Rad multi-analyst software, Bio-Rad Laboratories).

\section{STATISTICAL ANALYSES}

All data are represented as mean \pm SEM, where the mean values were obtained from the three replicate tanks per treatment. Mean value from the three replicate tanks were subjected to ANOVA, and the LSD test was used to discern differences among the means $(P<0.05)$.

\section{RESULTS}

No fish mortality was observed throughout the experimental period. Blood hematocrit and total hemoglobin were not affected throughout the study in either control or cold shock groups (Fig 1).

No differences in plasma cortisol or glucose levels were found between fish from control and cold shock groups. However, plasma cortisol and glucose levels changed within each treatment throughout the experimental period (Fig 2). Matrinxã subjected to cold shock had significantly higher plasma cortisol levels $1 \mathrm{~h}$ after the treatment (Fig 2a compared with cortisol levels before and immediately after the cold shock), and the values remained elevated up $12 \mathrm{~h}$ and then returned to basal levels. Fish from the control group had significantly higher plasma cortisol levels at $3 \mathrm{~h}$ (compared with levels before the transfer).

Plasma glucose profiles within each experimental group were similar to the plasma cortisol responses (Fig 2b). The cold-shock group had elevated plasma glucose levels $1 \mathrm{~h}$ after the cold shock, while control group had significantly 

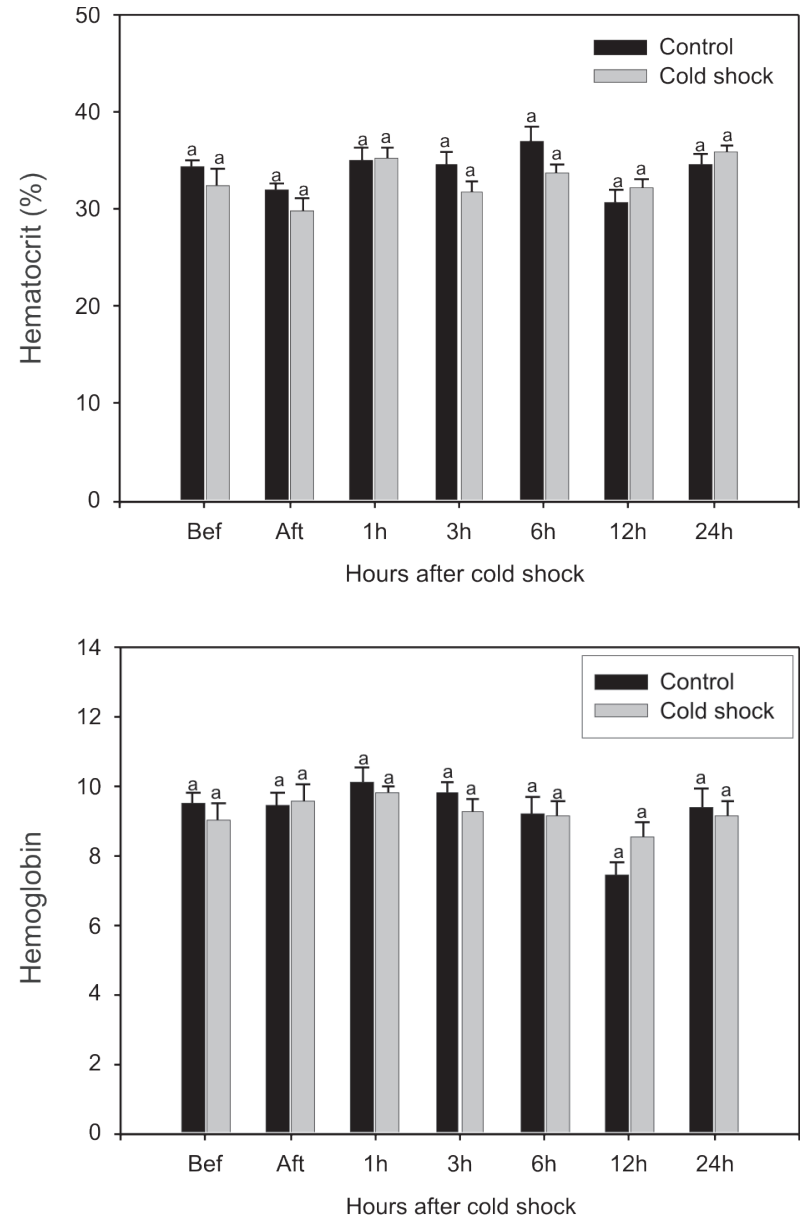

Figure 1 - Hematocrit (\%) (A) and total hemoglobin ( $\mathrm{g} / 100 \mathrm{~mL})(\mathrm{B})$ in juvenile matrinxã, Brycon amazonicus, subjected to a 1-h cold shock from $28^{\circ} \mathrm{C}$ to $18{ }^{\circ} \mathrm{C}$. Bef, refers to plasma values before the treatment. Aft, refers to values immediately after the treatment. Bars represent treatment mean values $(n=$ 3 , mean of each replicate) and error bars represent standard error of the mean (SEM). Same letter above the bars demonstrate no significant differences $(P>0.05)$ through time within each treatment.

increased values at $3 \mathrm{~h}$. Plasma glucose levels never returned to pre-treatment levels (compared with levels before) even in the control group. Constitutive levels of HSP70 were found in the gills and the values were similar between treatments (Fig 3).

\section{DISCUSSION}

The resting values of cortisol, glucose, hematocrit, and total hemoglobin represented a non-stressed state in matrinxã. Similar resting levels have also been reported in other studies in which matrinxã has been exposed to different stressors (Avilez et al., 2004; Carneiro \& Urbinati, 2001; Roubach et al., 2001).
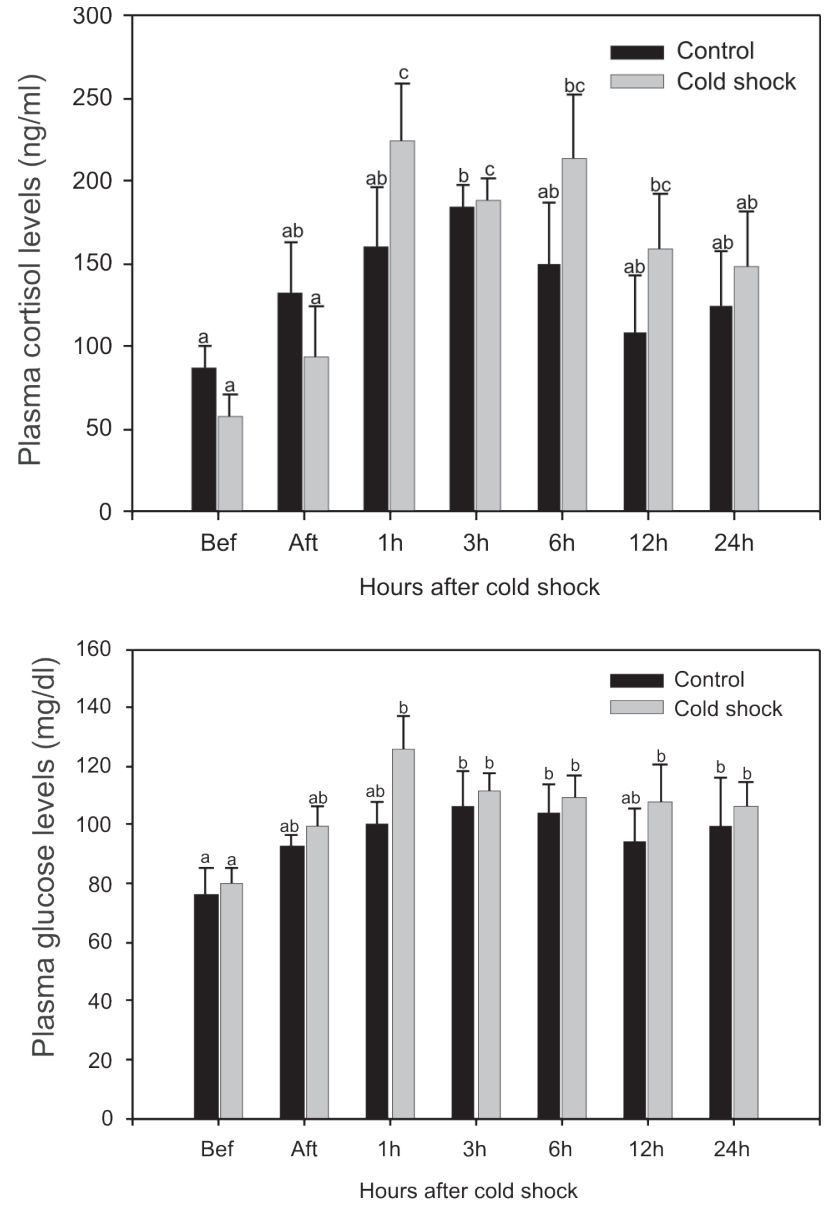

Figure 2 - Plasma cortisol (a) and glucose (b) in juvenile matrinxã subjected to a 1-h cold shock from $28^{\circ} \mathrm{C}$ to $18^{\circ} \mathrm{C}$. Bef, refers to plasma values before the treatment. Aft, refers to values immediately after the treatment. Bars represent treatment mean values ( $n=3$, mean of each replicate) and error bars represent standard error of the mean (SEM). Different letter above the bars demonstrate significant differences $(P<0.05)$ through time within each treatment.

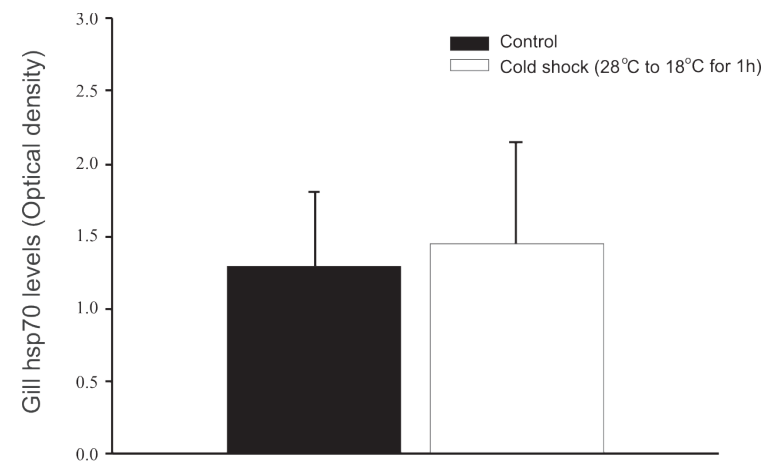

Figure 3. Band intensity of Gill HSP70 in juvenile matrinxã subjected to a 1hcold shock (from $28^{\circ} \mathrm{C}$ to $18^{\circ} \mathrm{C}$ ). Control groups were only exposed to the necessary handling to conduct the experimental cold shock. 
None of the physiological parameters we measured in matrinxã changed during the cold shock. Some of these parameters have been shown to change when fish are exposed to cold shock (In vivo studies: rainbow trout: Barton \& Peter, 1982; tilapia aurea: Chen et al., 2002, Kindle \& Whitmore, 1986; common carp: Tanck et al., 2000; milkfish: Hsieh et al., 2003; In vitro studies: rainbow trout RTG-2 cells: Yamashita et al., 1996; zebrafish ZF4 cells: Airaksinen et al., 2003). However, after fish had returned to the conditions prior to cold shock, a clear increase in plasma cortisol and glucose occurred in the cold-shock group. Therefore, we suggest that matrinxã may not evoke certain components of the stress response to deal with this level of short-term water temperature change. The lack of a significant stress response beyond that in the control group might be associated with the natural life history of this species, which inhabits warm waters throughout the year.

Hematocrit and hemoglobin levels did not change either during or after the experimental cold shock. Similarly, acute handling and exposure to the anaesthetic tricaine methanesulfonate did not elicit significant hematocrit changes in matrinxã (Roubach et al., 2001). However, these parameters have been shown to change in matrinxã exposed to other stressors. Nitrite in concentrations close to $\mathrm{LC}_{50}$ caused significant hematocrit, hemoglobin and metahemoglobin disturbances after 96h exposures (Avilez et al., 2004). Hauling and transportation also have elicited hematocrit changes in this species (Carneiro \& Urbinati, 2001; Urbinati \& Carneiro, 2001).

The levels of plasma cortisol and glucose in matrinxã immediately after the cold shock were similar to the values of control groups (not exposed to cold water). In vivo studies have demonstrated that some indicators of the stress response (such as cortisol) can change when fish are exposed to acute cold shock (Barton \& Peter, 1982; Tanck et al., 2000; Chen et al., 2002). However, to be able to make reliable comparisons it is important to consider the natural life history of the species being tested. Matrinxã lives in the Amazon basin where the water is naturally warm, and the temperature is constant throughout the year (Esteves, 1988). In the Amazon region, increase in the water temperature is a natural phenomenon for the aquatic organisms, but sudden drop in the water temperature is essentially absent. This natural history condition is important for understanding why matrinxã responded by increasing cortisol and glucose when transferred from $18^{\circ} \mathrm{C}$ to $28^{\circ} \mathrm{C}$, but not during the cold shock. Biological systems are shaped during evolution, and it is possible that in Amazon species the biochemical strategies evolved rather to cope with temperature increase than decrease. However, this study per se does not establish this. Further experiments should be carried out to investigate the stress response throughout the course of the cold shock. Furthermore, it would be important to expose matrinxã not only to acute cold shock, but also to long-term acclimation to lower temperatures.

There are only a few in vivo studies on cold shock effects on the stress response in fish. None of them, however, has investigated the endocrine and cellular stress responses concomitantly. One of these studies used common carp as a model (Tanck et al. 2000). Differently from matrinxã, common carp is adapted to subtropical conditions and it has a wider temperature tolerance range (Tanck et al. 2000). Common carp had significantly elevated plasma cortisol and lactate (but not glucose) levels when subjected to an acute cold shock (from $25^{\circ} \mathrm{C}$ to $14^{\circ} \mathrm{C}$ ). Plasma cortisol levels increased approximately $20 \mathrm{~min}$ after the onset of the experimental cold shock and remained significantly elevated throughout the cold shock. Also contrasting to our results, plasma cortisol levels did not increase after water temperature had returned to $25^{\circ} \mathrm{C}$ (Tanck et al. 2000). Rainbow trout, a cold-water fish, subjected to an abrupt cold temperature change (from $9^{\circ} \mathrm{C}$ to $1^{\circ} \mathrm{C}$ ) showed increased plasma cortisol levels at $4 \mathrm{~h}$ after, and the values remained elevated for up to 2 days (Barton \& Peter, 1982). Tilapia aurea exposed to cold shock (from $25{ }^{\circ} \mathrm{C}$ to $13{ }^{\circ} \mathrm{C}$ during 30-120 min) also increased plasma cortisol levels not only during the cold stress, but also 1-2 days after (Chen et al., 2002). Under experimental conditions the lower lethal temperature is between $6-9^{\circ} \mathrm{C}$, demonstrating that this species is able to tolerate cold temperature (Chervinski \& Lahav, 1976; Shafland \& Pestrak, 1982). Collectively, these studies demonstrated that fish can elicit an endocrine response during cold shock and this response is probably evoked to help the animal to deal with the insult, as it is presumed to do for other stressors (Barton \& Iwama, 1991). However, it is important to consider that these species can naturally survive in environments with low water temperature. Therefore, their response to a cold shock may differ from species such as matrinxã that have not evolved in an environment where water temperatures can get very low seasonally or even daily. Although possibly the lack of response in matrinxã is directly related to their natural history life, we cannot rule out that an increase in those parameters happened, but was not detected, since we did not sample fish throughout the cold shock period. It is equally difficult to explain the lack of endocrine response. One possibility is that the activity of the enzymes involved in steroid and glucose synthesis were altered (possibly down-regulated) by the low temperature. It is also possible that the cold shock period was not either severe or long enough to allow a physiological response to be elicited. We pushed fish very close to their tolerance limits. Guimarães \& Storti-Filho (2003) exposed matrinxã to a range of temperatures (from 12 to $39^{\circ} \mathrm{C}$ ) and demonstrated that the 
low temperature limit was $18^{\circ} \mathrm{C}$. The authors also showed that at $15^{\circ} \mathrm{C}$ mortality started to occur immediately after the transfer to the cold-water. Further research is necessary to determine whether a long-term cold shock would elicit a physiological response in matrinxã. The lack of response would evidence the inability to adapt to cold, which could eventually lead to fish death. Indeed, mass mortality of matrinxã has been observed in aquaculture facilities close to subtropical areas.

In this study, matrinxã did not induce synthesis of HSP70 either during the cold shock or during the recovery from the insult. It is possible that, due to its ectothermic nature, the fish down-regulated their metabolism during the cold shock and therefore decreased protein synthesis. This is the first in vivo study in tropical fish examining the HSP70 response during cold shock. Usually induction of HSP70 synthesis occurs to protect thermally denaturated proteins. HSP70 binds to the denaturated protein, prevents its aggregation and facilitates the re-folding to its native form (Hoffman et al., 2000). If cold shock did not cause denaturation of proteins, but did cause a transient inhibition of some cellular proteins (Etchegaray \& Inouye, 1999), the lack of HSP70 response in matrinxã makes sense. Atlantic salmon exposed to a $2 \mathrm{~h}, 12^{\circ} \mathrm{C}$ cold shock (from $16^{\circ} \mathrm{C}$ to $4^{\circ} \mathrm{C}$ ) did not increase HSP70 mRNA levels (Zarate \& Bradley, 2003). An in vitro study using a cell line of a tropical fish (zebrafish ZF4) did not show HSP70 induction during cold shock (Airaksinen et al., 2003). It might be possible that other proteins are induced to help the animals to cope with the cold shock. It has been shown in E. coli that cold shock induces the synthesis of several proteins collectively known as the cold shock proteins (CSPs) (Etchegeray and Inouye, 1999). Further investigation would be necessary to see if these proteins would also be induced in fish.

In our study, fish were subjected to a heat shock of +10 ${ }^{\circ} \mathrm{C}$ (from $18^{\circ} \mathrm{C}$ back to $28^{\circ} \mathrm{C}$ ) $1 \mathrm{~h}$ after the cold shock before the recovery period and still no induction of HSP70 synthesis was observed. There is no similar work either in tropical or temperate fish. Flies, however, induce HSP70 during the recovery from cold shock (Burton et al., 1988; Joplin et al., 1990; Nunamaker et al., 1996). Plasma cortisol and glucose levels significantly increased during the recovery period, demonstrating that matrinxã was sensitive to the repeated disturbances (handling + heat shock). We suspect that the lack of HSP70 response was also influenced by the natural life history of this species. Matrinxã lives in the Amazon Basin, which is an environment with warm and steady water temperatures (Esteves, 1988). It has been demonstrated that most organisms elicit an HSP70 response when subjected to $5-10{ }^{\circ} \mathrm{C}$ above their normal temperature range (Liquidist, 1986). Therefore, it may be possible that the $10^{\circ} \mathrm{C}$ increase in temperature, which made the fish return to their normal temperature range, was not enough to elicit a heat shock response. Similarly, tilapia (Oreochromis mossambicus) did not elicit a heat shock response when subjected to an increase in water temperature within their normal temperature range (Basu et al., 2001).

In conclusion, our data demonstrated that matrinxã, an Amazonian fish, did not elicit a characteristic stress response during cold shock. But plasma cortisol and glucose levels increased during the recovery period. This study also showed for the first time that HSP70 is present at constitutive levels in matrinxã, although concentrations also did not change from the cold shock.

\section{ACKNOWLEDGMENTS}

Grants from the National Research Council of Canada (NRC-IMB), and the funding agencies from Brazil "Conselho Nacional Conselho Nacional de Desenvolvimento Científico e Tecnológico (CNPq 141595/01-9, 150666/2005-5)", and "Coordenação de Aperfeiçoamento de Pessoal de Nível Superior (Capes BEX 1154/03-6)" supported this work. We are grateful to Dr. Bruce Barton for his constructive comments. We are also indebted to our friends from our labs for the assistance during this work.

\section{LITERATURE CITED}

Afonso, L.O.B.; Basu, N., Nakano, K.; Devlin, R.H.; Iwama, G.K. 2004. Sex-related differences in the organismal and cellular stress response in juvenile salmon exposed to treated bleached kraft mill effluent. Fish Physiol. Biochem., 29: 173-179.

Airaksinen, S.; Jokiletho, T.; Raabergh, C.M.; Nikinmaa, M. 2003. Heat and cold inducible regulation of Hsp-70 expressions in zebrafish ZF4 cells. Comp. Biochem. Physiol. B, 136 (2): 275282.

Arana, L.V. 1997. Princípios químicos da qualidade da água em aqüicultura. Editora da UFSC, Florianópolis,Brazil. 166 p.

Avilez, I.; Altran, A.; Aguiar, L.; Moraes, G. 2004. Hematological responses of the neotropical teleost matrinxã Brycon cephalus to environmental nitrite. Comp. Biochem. Physiol. C, 139 (1-3): 135-139.

Barton, B.A.; Iwama, G.K. 1991. Physiological changes in fish from stress in aquaculture with emphasis on the response and effects of corticosteroids. Ann. Rev. of Fish Diseases, 1: 3-26.

Barton, B.A.; Peter, R.E. 1982. Plasma cortisol stress response in fingerling rainbow trout Salmo gairdneri to various transport conditions, anaesthesia, and cold shock. Journal of Fish Biology, 20: 39-51.

Basu, N.; Nakano,T.; Grau, E.G.; Iwama, G.K. 2001. The effects of cortisol on heat shock protein 70 levels in two fish species. Gen. Comp. Endocrinol., 124: 97-105.

Basu, N.; Todgham, A.E.; Ackerman, P.A.; Bibeau, M.R.; Nakano, K.; Schulte, P.M.; Iwama, G.K. 2002. Heat shock protein genes and their functional significance in fish. Gene, 295: 173-183. 
Burton, V.; Mitchell, H.; Young, P.; Petersen, N. 1988. Heat shock protection against cold stress of Drosophila melanogaster. Mol. Cel. Biol., 8(8): 3550-3552.

Carneiro, P.C.F.; Urbinati, E.C. 2001. Salt as a stress response mitigator of matrinxã Brycon cephalus (Gunther, 1869) during transport. Aquaculture Research, 32: 297-304.

Collier, H.B. 1944. The standadization of blood haemoglobin determinations. Can. Med. Assoc. J., 50: 550-552.

Chen, W.; Sun, L.; Tsai, C.; Song, Y.; Chang, C. 2002. Coldstress induced the modulation of catecholamines, cortisol, imunoglobulin M, and leukocyte phagocytosis in tilapia. Gen. Comp. Endocrin., 126: 90-100.

Chervinski, J.; Lahav, M. 1976. The effect of exposure to low temperature on fingerlings of local tilapia (Tilapia aurea) (Steindachner) and imported tilapia (Tilapia vulcani)(Trewevas) and Tilapia nilotica (Linne) in Israel. Bamidgeh, 28(1/2): 2529.

Drabkin, D. 1948. The standardization of hemoglobin measurement. Am. J. Med. Sci., 215(1): 110-111.

DuBeau, S.F.; Pan, F.; Tremblay, G.C.; Bradley, T.M. 1998. Thermal shock of salmon in vivo induces the heat shock protein hsp 70 and confers protection against osmotic shock. Aquaculture, 168: 311-323.

Esteves, F. 1988. Fundamentos de Limnologia. Editora InterciênciaFinep, 575p.

Etchegaray, J.P.; Inouye, M. 1999. CspA, CspB, and CspG, major cold shock proteins of Escherichia coli, are induced at low temperature under conditions that completely block protein sysnthesis. J. Bacteriol., 181: 1827-1830.

Guimarães, S.; Storti Filho, A. 2003. Preliminary observations on the effect of sudden changes of temperature on survival of young matrinxã (Brycon cephalus) under laboratory conditions. Acta Amazonica, 33(4): 719-722.

Hofmann, G.E.; Buckley, B.A.; Airaksinen, S.; Keen, J.E.; Somero, G.N. 2000. Heat-shock protein expression is absent in the Antarctic fish Trematomus bernacchii (family Nototheniidae). Journal of Experimental Biology, 203: 2331-2339.

Hsieh, S.L.; Chen, Y.N.; Kuo, C.M. 2003. Physiological responses, desaturase activity, and fatty acid composition in milkfish (Chanos chanos) under cold acclimation. Aquaculture, 220: 903-908.

Iwama, G.; Afonso, L.; Todgham, A.; Ackerman, P.; Nakano, K. 2004. Are Hsps suitable for indicating stressed states in fish? Journal of Experimental Biology, 204: 15-19.

Joplin, K.; Yocum, G.; Denlinger, D. 1990. Cold shocks elicits expression of heat shock proteins in the flesh fly Sarcophaga crassipalpis. J. Insect Physiol., 36(11): 825-834.

Ju, Z.; Dunham, R.A.; Liu, Z. 2002. Differential gene expression in the brain of channel catfish (Ictalurus punctatus) in response to cold acclimation. Mol. Gen. Genom., 268: 87-95.

Kindle, K.R.; Whitmore, D.H. 1986. Biochemical indicators of thermal stress in Tilapia aurea (Steindachner). J. Fish Biol., 29: 243-255.
Laemmli, I.K. 1970. Cleavage of structural proteins during the assembly of the head of bacteriophage T4. Nature, 227: 680685.

Lindquist, S. 1986. The heat-shock response. Ann. Rev. Biochem., 55: 1151-1191.

Nunamaker, R.; Dean, V.; Murphy, K.; Lockwood, A. 1996. Stress protein elicited by cold shock in the biting midge Culicoides variipennis sonorensis Wirth and Jones. Comp. Bioch. Physiol. $B, 113: 73-77$.

Palmisano, A.N.; Winton, J.R.; Dickhoff, W.W. 2000. Tissuespecific induction of hsp90 mRNA and plasma cortisol response in chinook salmon following heat shock, seawater challenge, and handling challenge. Mar. Biotechnol., 2: 329-338.

Roubach, R.; Gomes, L.; Val, A. 2001. Safest level of tricaine methanesulfonate (MS 222) to induce anesthesia in juveniles of matrinxã, Brycon cephalus. Acta Amazonica, 31(1): 159-163.

Shafland, P.L.; Pestrak, J.M. 1982. Lower lethal temperatures for fourteen non-native fishes in Florida. Environ. Biol. Fish., 7(2): 149-156.

Tanck, M.; Booms, G.; Eding, E.; Wendelaar Bonga, S.; Komen, J. 2000. Cold shocks: a stressor for common carp. J. Fish Biol., 57: 881-894.

Trinder, P. 1969. Determination of glucose in blood using glucose oxidase with an alternative oxygen acceptor. Annal. Clin. Biochem., 6: 24-27.

Urbinati, E.; Carneiro, P. 2001. Metabolic and hormonal responses of matrinxã Brycon cephalus, (Teleost: Characidae) to transport stress under influence of benzocaine. J. Aquac. Trop., 16 (1): 75-85.

Vijayan, M.M.; Pereira, C.; Forsyth, R.B.; Kennedy, C.J.; Iwama, G.K. 1997. Handling stress does not affect the expression of hepatic heat shock protein 70 and conjugation heat shock cognate hsc 71 gene from rainbow trout. Eur. J. Biochem., 204: 893-900.

Washburn, B.S.; Moreland, J.J.; Slaughter, A.M.; Werner, I.; Hinton, D.E.; Sanders, B.M. 2002. Effects of handling on heat shock protein expression in rainbow trout (Oncorhynchus mykiss). Environ. Toxicol. Chem., 21: 557-560. Yamashita, M.; Ojima, N.; Sakamoto, T. 1996. Induction of protein in response to cold acclimation of rainbow trout cells. FEBS Letters, 382: 261-264.

Zarate, J.; Bradley, T.M. 2003. Heat shock proteins are not sensitive indicators of hatchery stress in salmon. Aquaculture, 223: 175187.

Recebido em 01/05/2006

Aceito em 25/06/2008 
